University of Nebraska - Lincoln

DigitalCommons@University of Nebraska - Lincoln

1999

\title{
Grassland Vegetation Changes and Nocturnal Global Warming
}

Richard D. Alward

University of Nebraska-Lincoln

James K. Detling

Colorado State University - Fort Collins

Daniel G. Milchunas

Colorado State University - Fort Collins

Follow this and additional works at: https://digitalcommons.unl.edu/bioscifacpub

Part of the Life Sciences Commons

Alward, Richard D.; Detling, James K.; and Milchunas, Daniel G., "Grassland Vegetation Changes and Nocturnal Global Warming" (1999). Faculty Publications in the Biological Sciences. 150.

https://digitalcommons.unl.edu/bioscifacpub/150

This Article is brought to you for free and open access by the Papers in the Biological Sciences at DigitalCommons@University of Nebraska - Lincoln. It has been accepted for inclusion in Faculty Publications in the Biological Sciences by an authorized administrator of DigitalCommons@University of Nebraska - Lincoln. 


\title{
Grassland Vegetation Changes and Nocturnal Global Warming
}

Richard D. Alward, Graduate Degree Program in Ecology and Natural Resource Ecology Laboratory, Colorado State University, Fort Collins, CO 80523, USA. Corresponding author - Present address: School of Biological Sciences, University of Nebraska-Lincoln, Lincoln, NE 68588, USA. E-mail: ralward1@unl.edu

James K. Detling, Department of Biology and Natural Resource Ecology Laboratory, Colorado State University, Fort Collins, CO 80523, USA

Daniel G. Milchunas, Department of Rangeland Ecosystem Science and Natural Resource Ecology Laboratory, Colorado State University, Fort Collins, CO 80523, USA

\begin{abstract}
Global minimum temperatures $\left(T_{\mathrm{MIN}}\right)$ are increasing faster than maximum temperatures, but the ecological consequences of this are largely unexplored. Long-term data sets from the shortgrass steppe were used to identify correlations between $T_{\text {MIN }}$ and several vegetation variables. This ecosystem is potentially sensitive to increases in $T_{\text {MIN }}$. Most notably, increased spring $T_{\text {MIN }}$ was correlated with decreased net primary production by the dominant $\mathrm{C}_{4}$ grass (Bouteloua gracilis) and with increased abundance and production by exotic and native $C_{3}$ forbs. Reductions in $B$. gracilis may make this system more vulnerable to invasion by exotic species and less tolerant of drought and grazing.
\end{abstract}

There is general consensus that there is an anthropogenic warming signal in the long-term climate record (1). Over land, this is primarily due to average annual minimum temperatures $\left(T_{\text {MIN }}\right)$ having increased at twice the rate of maximum temperatures $\left(T_{\mathrm{MAX}}\right)$ $(1,2)$. At the global scale, these increases in $T_{\text {MIN }}$ are related to increases in global cloudiness $(1,3)$. Experiments with agricultural plants and insect pests suggest important roles for $T_{\text {MIN }}$ in influencing plant and insect development $(4,5)$. However, there has been little research on the consequences of elevated $T_{\text {MIN }}$ for natural ecosystems $(6,7)$. If elevated $T_{\text {MIN }}$ leads to longer growing seasons, net primary production and carbon sequestration may increase as a consequence (8). However, the opposite may occur if elevated $T_{\text {MIN }}$ leads to increased plant and microbial nocturnal respiration rates without a compensatory increase in photosynthesis. Additionally, elevated $T_{\text {MIN }}$ could shift competitive interactions among $\mathrm{C}_{3}$ (cool-season) and $\mathrm{C}_{4}$ (warm-season) plants.

It is important to identify features of ecosystems that are sensitive to changes in $T_{\text {MIN }}$. To date, most modeling efforts and experimental manipulations investigating ecosystem responses to climate change have assumed that future warming will occur primarily during the day or uniformly over the diurnal cycle. This assumption clearly is not valid on a global level nor at most regional scales (2). Furthermore, there is no a priori reason to assume that ecosystems will respond similarly to changes in $T_{\text {MIN }}$ and $T_{\text {MAX }}$. To investigate potential ecological consequences of elevated $T_{\text {MIN }}$, we examined a 23-year data set for correlations between temperature [ $T_{\text {MIN }}$ $T_{\text {MAX, }}$ and mean annual temperature $\left.\left(T_{\text {AVE }}\right)\left(T_{\text {AVE }}=\left(T_{\text {MIN }}+T_{\text {MAX }}\right) / 2\right)\right]$ and both the abundance and aboveground net primary productivity (ANPP) of several key plant species and functional groups found at the Central Plains Experimental Range (9) in northeastern Colorado.

We identified seasonal and annual trends in $T_{\text {MIN }}$ and $T_{\text {MAX }}$ to determine whether asymmetric diurnal temperature increases held true for this site (10). The densities of most species were determined by counting all individuals within permanently marked quadrats (11). Harvests at time of peak standing crop were used as estimates of ANPP $(12,13)$. Plants in the shortgrass steppe are commonly waterlimited, and variation in precipitation could obscure plant responses to gradually changing temperatures $(9,14)$. Therefore, we included annual and seasonal precipitation totals, in addition to annual and seasonal minimum and maximum temperatures, as vari- ables for stepwise regression model selection (15). We constructed linear models to evaluate significant correlations between these variables and ANPP or plant species density (16).

Mean annual temperatures $\left(T_{\text {AVE }}\right)$ have increased by an average of $0.12^{\circ} \mathrm{C}$ year ${ }^{-1}$ at this site since $1964\left(P=0.0001, R^{2}=0.52\right)$. During this period, $T_{\text {MAX }}$ increased $0.085^{\circ} \mathrm{C}$ year ${ }^{-1}$ (Figure 1A), whereas $T_{\mathrm{MIN}}$ increased $0.15^{\circ} \mathrm{C}$ year ${ }^{-1}$ (Figure 1B). We limited further analyses of temperature to the period beginning in 1970, when standardized monitoring of vegetation density was initiated. Since 1970, $T_{\mathrm{AVE}}$ has risen over $1.3^{\circ} \mathrm{C}$, largely due to a significant increase in $T_{\mathrm{MIN}}$ of $0.12^{\circ} \mathrm{C}$ year $^{-1}\left(P=0.003 ; R^{2}=0.44\right)$. However, there was no significant trend for $T_{\text {MAX }}(P=0.49)$. Averages of seasonal minimum temperatures since 1970 also exhibited significant warming, with similar trends in winter $\left(0.17^{\circ} \mathrm{C}\right.$ year-1, $\left.P=0.0013, R^{2}=0.40\right)$, spring $\left(0.16^{\circ} \mathrm{C}\right.$ year $\left.{ }^{-1}, P=0.0007, R^{2}=0.43\right)$, and summer $T_{\mathrm{MIN}}\left(0.12^{\circ} \mathrm{C}\right.$ year ${ }^{-1}$, $\left.P=0.004, R^{2}=0.33\right)$. No significant trends were detected in fall $T_{\text {MIN }}(P$ $\left.=0.64, R^{2}=0.01\right)$. Annual precipitation (Figure 1C) varied from 230 to $480 \mathrm{~mm}$ and has also exhibited a significant linear increase since 1970 (6 mm year-1, $\left.P=0.007, R^{2}=0.30\right)$. However, there were no significant correlations between annual or seasonal $T_{\mathrm{MIN}}$ and an- 
nual or seasonal precipitation $(P>0.1)$.

Since 1983 (12), ANPP of Bouteloua gracilis, the dominant $C_{4}$ grass of the shortgrass steppe, declined over time $\left(-12.2\right.$ g m$^{-2}$ year $\left.{ }^{-1} ; P=0.002 ; R^{2}=0.78\right)$, and was negatively correlated with average spring $T_{\text {MIN }}$ (Figure 2A). ANPP of the most abundant $\mathrm{C}_{3}$ forb, Sphaeralcea coccinea, was negatively correlated with winter $T_{\text {MIN }}$ (Figure 2B). In contrast, ANPP of both the $\mathrm{C}_{3}$ sedge Carex eleocharis (Figure 2C) and of all $\mathrm{C}_{3}$ forbs combined (Figure 2D) was positively correlated with fall and summer $T_{\text {MIN }}$, respectively. Plant density was also correlated with $T_{\text {MIN }}$. Exotic forb density was positively correlated with spring $T_{\text {MIN }}$ (Figure 2E), whereas the density of the $C_{3}$ grass Sitanion hystrix was positively correlated with winter $T_{\text {MIN }}$ (Figure $2 \mathrm{~F}$ ).

The relationships between $T_{\text {MIN }}$ and vegetation revealed by these analyses highlight potential effects of climate change on natural ecosystems. This shortgrass steppe site has experienced increases in $T_{\text {MIN }}$ over the past few decades that are similar to trends

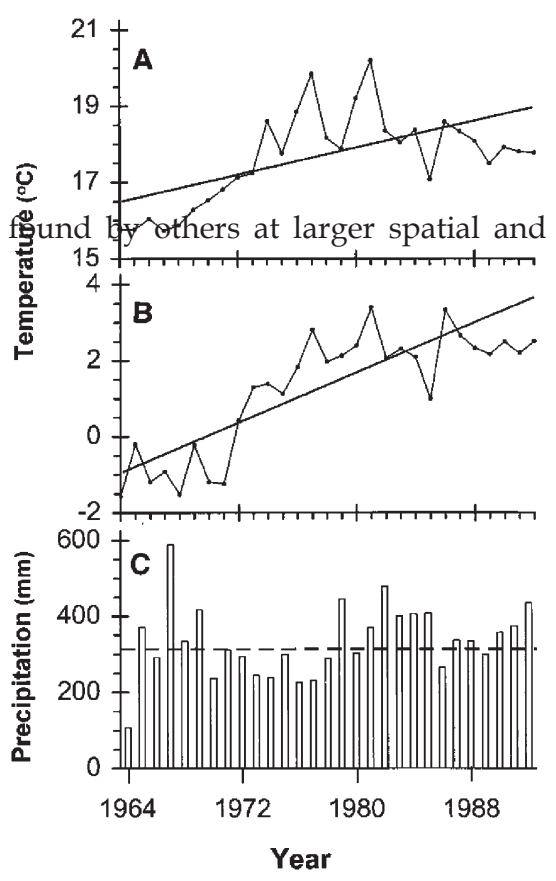

Figure 1. Summary of climate data for the Central Plains Experimental Range site. (A) Average annual $T_{\text {MAX }}$. The heavy line is the significant linear trend in $T_{\text {MAX }}$ $\left[T_{\operatorname{MAX}}=-150+0.085\right.$ (year); $P=0.001 ;$ $R^{2}=0.36$. (B) Average annual $T_{\mathrm{MIN}}$. The heavy line is the significant linear trend in $T_{\text {MIN }}\left[T_{\text {MIN }}=-299+0.15\right.$ (year); $\left.P=3.3 \times 10^{-8} ; R^{2}=0.68\right]$. (C) Total annual precipitation. The horizontal dashed line identifies the average annual precipitation (323 mm) at this site since 1939. temporal scales (2). For each $1^{\circ} \mathrm{C}$ increase in average spring $T_{\mathrm{MIN}^{\prime}}$ ANPP of the dominant grass decreased by nearly one-third (Figure 2A). Because this one species (B. gracilis) represents an average of $66 \%$ of total ANPP and nearly $90 \%$ of the total basal cover (9), this result has serious implications for both the structure and function of the shortgrass steppe, if its productivity is causally related to $T_{\mathrm{MIN}}$. Bouteloua gracilis is a drought- and grazing-tolerant species that makes up as much as $40 \%$ of the diet of cattle on the shortgrass steppe (17). A major reduction in this species could have substantial consequences for livestock production if it were not replaced by other palatable species. Also of concern is the increase in exotic forb density, because invasive exotic plants are already recognized as a threat to the structure and function of numerous natural ecosystems (18); increasing $T_{\text {MIN }}$ may exacerbate this threat.

Elevated $T_{\text {MIN }}$ may have direct, but counterbalancing, effects on ANPP and the abundance of plants through mechanisms such as increased rates of carbon assimilation due to warmer mornings, accelerated carbon loss through increased rates of respiration due to warmer nights, and differential effects on $\mathrm{C}_{3}$ - versus $\mathrm{C}_{4}$-photosynthesizing plants. Positive correlations between $T_{\text {MIN }}$ and both forb ANPP
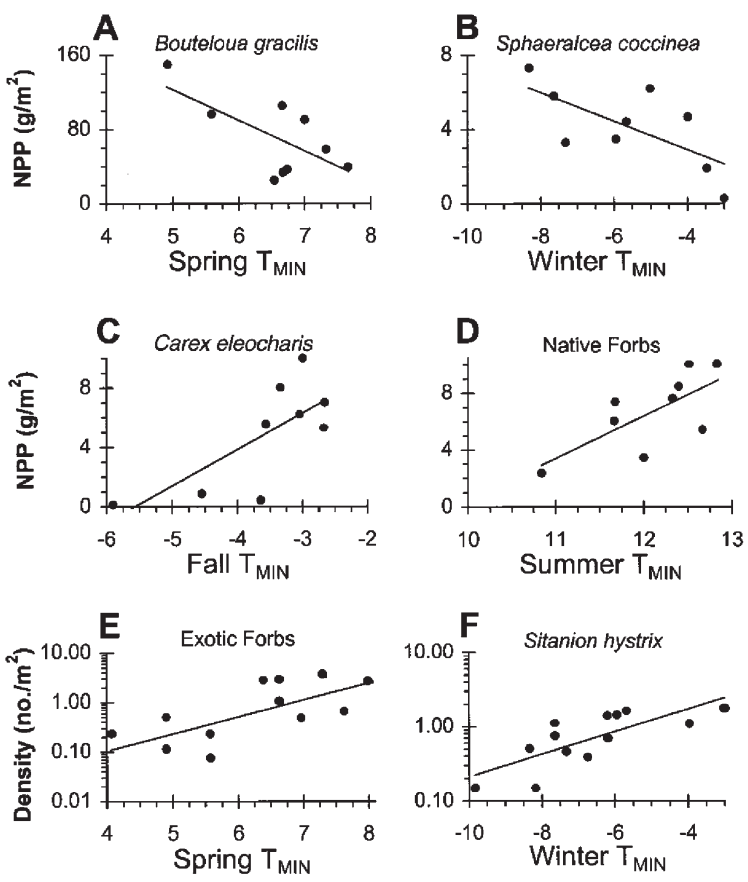

Average seasonal temperature $\left({ }^{\circ} \mathrm{C}\right)$ and exotic plant densities (Figure 2, D and E) support the hypothesis that increased production will be observed in some plants, and the negative correlation between $T_{\mathrm{MIN}}$ and $B$. gracilis ANPP (Figure 2A) is consistent with the increased respiration hypothesis. In addition to direct effects on rates of plant physiological processes, increases in $T_{\text {MIN }}$ could affect plant growth indirectly through changes in the length of growing seasons through increased duration of the frost-free period or changes in the availability of soil water. An increase in season duration would be expected to primarily benefit cool-season plants that are growing most rapidly, and preemptively consuming resources, early and late in the growing season. The positive correlation between spring $T_{\text {MIN }}$ and exotic $\mathrm{C}_{3}$ forbs (Figure 2E) and between fall $T_{\text {MIN }}$ and C. eleocharis (Figure $2 \mathrm{C}$ ) is consistent with this hypothesis.

Some of the correlations could be the result of effects of elevated $T_{\text {MIN }}$ on biotic interactions. Some plants may be increasing (Figure 2, C through F) in response to the decrease in $B$. gracilis ANPP and the consequent increase in availability of space, nutrients, or water, rather than because of any direct effects of elevated $T_{\text {MIN }}$ on these plants. Alternatively, if increased $T_{\text {MIN }}$ benefits the growth of $\mathrm{C}_{3}$ plants (Figure 2, $\mathrm{C}$ through $\mathrm{F}$ ), this could subrelations with seasonal average $T_{\text {MIN }}$ (A) Bouteloua gracilis and spring $T_{\text {MIN }}$ [ANPP $=288-33.1\left(T_{\text {MIN }}\right)$; $\left.P=0.039 ; R^{2}=0.48\right]$. (B) Sphaeralcea coccinea and winter $T_{\text {MIN }}$ [ANPP $=0.149-0.77\left(T_{\text {MIN }}\right)$; $\left.P=0.038 ; R^{2}=0.48\right]$. $(\mathbf{C})$ Carex eleocharis and fall $T_{\text {MIN }}$ [ANPP $=13.6+2.44\left(T_{\text {MIN }}\right)$; $\left.P=0.019 ; R^{2}=0.56\right]$. (D) Native forb (herbaceous dicots) and summer $T_{\text {MIN }}$ [ANPP $=-29.5+2.99\left(T_{\text {MIN }}\right)$; $\left.P=0.028 ; R^{2}=0.52\right]$. (E) Exotic (nonnative) forb density and spring $T_{\text {MIN }}$ [density $=0.008 e^{0.71\left(T_{\mathrm{MIN}}\right) \text {; }}$; $\left.P=0.014 ; R^{2}=0.46\right]$. (F) Sitanion hystrix density and winter $T_{\text {MIN }}$ [density $\left.\left.=6.4 e^{0.33(T}\right)^{\prime}\right)$; $\left.P=0.002 ; \quad R^{2}=0.57\right]$ Methods for obtaining density and ANPP data are described in $(11,12)$. 
sequently result in negative effects on the $\mathrm{C}_{4}$ B. gracilis (Figure 2A). Such a scenario might occur if cool-season plants were able to reduce available soil moisture before the period of rapid growth of warm-season plants. Intertrophic interactions might also be affected. If increased developmental and consumption rates by insects in response to elevated $T_{\text {MIN }}(4)$ are common, increased herbivory could alter plant responses to climate change.

Without a clear causal link, there is no compelling evidence to eliminate factors other than increased $T_{\mathrm{MIN}}$ as causes of observed changes in ANPP and plant densities. Unfortunately, most experiments and models designed to investigate climate change effects have focused on manipulating $T_{\text {MAX }}$ or have assumed equal contributions by $T_{\text {MIN }}$ and $T_{\text {MAX }}$ toward achieving an increase in $T_{\mathrm{AVE}}$. The outcomes of such experiments may not realistically predict the future structure and dynamics of ecosystems if climate change continues to be manifested primarily as increases in $T_{\text {MIN }}$. There is a need for experiments that define the relationship between $T_{\text {MIN }}$, plant abundance, and ANPP and that identify mechanisms behind the relationship.

\section{References and Notes}

1. Intergovernmental Panel on Climate Change (IPCC), Climate Change 1995: The Science of Climate Change, J. T. Houghton et al., Eds. (Cambridge Univ. Press, Cambridge, 1995).

2. G. Kukla, T. Karl, M. Riches, Eds., Asymmetric Change of Daily Temperature Range: Proceedings of the International MINIMAX WORKSHOP, College Park, MD, 27 to 30 September 1993 [U.S. Department of Energy (DOE), Washington, DC, 1994]; T. R. Karl, D. R. Easterling, R. W. Knight, P. Y. Hughes, in Trends '93: A Compendium of Data on Global Change, T. A. Boden, D. P. Kaiser, R. J. Sepanski, F. W. Stoss, Eds. (ORNL) CDIAC-65, Carbon Dloxide Information Analysis Center, Oak Ridge National Laboratory, Oak Ridge, TN, 1994), pp. 686-736; D. R. Easterling, et al., Science 277, 364 (1997) .
3. A. Henderson-Sellars, Geojournal 27, 255 (1992); A. Dai, A . D. Del Genio and I. Y. Fung, Nature 386, 665 (1997).

4. Y. Yang and N. E. Stamp, Oecologia 104, 225 (1995).

5. M. Seddigh, G. D. Jolliff, J. H. Orf, Crop Sci. 29, 400 (1989); C. A. Zeiher, P. W. Brown, J. C. Silvertooth, N. Matumba, N. Milton, in Cotton: A College of Agriculture Report, J. Silvertooth, Ed. (University of Arizona, Tucson, AZ, 1994), pp. 89-96; P. Manunta and M. B. Kirkham, J. Agron. Crop Sci. 176, 267 (1996) .

6. H. A. Mooney, G. W. Koch, C. B. Field, in Asymmetric Change of Daily Temperature Range, G. Kukla, T. Karl, M. Riches, Eds. (DOE, Washington, DC, 1994), pp. 467-484.

7. R. A. Kerr, Science 255, 682 (1992) ; ibid. 268, 1567 (1995); ibid. 270, 1565 (1995).

8. M. B. Coughenour and D.-X. Chen, Ecol. Appl. 7, 802 (1997); R. B. Myneni, C. D. Keeling, C. J. Tucker, G. Asrar, R. R. Nemani, Nature 386, 698 (1997) .

9. For site descriptions, see D. G. Milchunas, W. K. Lauenroth, P. L. Chapman, M. K. Kazempour, Vegetatio 80, 11 (1989); W. K. Lauenroth and D. G. Milchunas, in Ecosystems of the World, R. T. Coupland, Ed. (Elsevier, Amsterdam, 1991), vol. 8A, chap. 11.

10. Daily $T_{\text {MIN }}$ and $T_{\text {MAX }}$ were used to calculate monthly averages; monthly data were used to calculate seasonal averages identified as winter (JanuaryMarch), spring (April-June), summer (July-September) and the previous fall (October-December).

11. D. G. Milchunas, W. K. Lauenroth, P. L. Chapman, M. K. Kazempour, J. Veg. Sci. 1, 375 (1990); D. G. Milchunas and W. K. Lauenroth, Ecology 73, 593 (1992); Ecol. Appl. 5, 452 (1995).

12. In August or September of each year, all vegetation within $15 \quad 0.25-\mathrm{m}^{2}$ circular quadrats was harvested, sorted, and dried. We restricted analyses of ANPP to data collected in 1983-1992, because the method used during these years was different from that used before 1983.

13. The following species and functional groups were represented in the analyses: Artemesia frigida, Aristida Iongiseta, Bouteloua gracilis, Carex eleocharis, Kochia scoparia, Opuntia polyacantha, Sitanion hystrix, and Sphaeralcea coccinea, warm-season grasses, cool-season grasses and sedges, annual grasses, all grasses and sedges combined, forbs (native herbaceous dicots), exotic (nonnative) forbs, dwarf shrubs, and total biomass from all species. Species richness was also analyzed.

14. O. E. Sala, W. J. Parton, L. A. Joyce, W. K. Lauenroth, Ecology 69, 40 (1988); D. G. Milchunas, J. R. Forwood, W. K. Lauenroth, J. Range Manage. 47, 133 (1994) .

15. The timing of vegetation measurements determined appropriate precipitation variables. Plant density was measured in early July. Although in July, August, and September potential evapotranspiration exceeds precipitation, these dry months would not affect July plant density. Thus, in addition to total annual (January-December) precipitation, "seasonal" precipitation totals included "useful" annual precipitation (OctoberJune) and winter (October-March) and spring (April-June) precipitation. However, ANPP was measured in September; thus the seasonal precipitation totals used in the ANPP analyses included total annual (January-December), useful annual (October-September), winter (October-March), spring (AprilJune), and summer (July-September) precipitation.

16. Significant correlations were identified with a stepwise model-building routine [SAS, version 6.11 (SAS Institute, Cary, NC, 1996); PROC REG with STEPWISE method; enter and exit $\alpha=0.1$ ]. Plant density values were log-transformed. We report the single factor that explained the most variation in each species' responses.

17. R. W. Rice and M. Vavra, US IBP Grassland Biome Technical Report No. 103 (Colorado State University, Fort Collins, CO, 1971).

18. D. A. Wedin and D. Tilman, Science 274, 1720 (1996) ; A. N. Cohen and J. T. Carlton, ibid. 279, 555 (1998); T. J. Stohlgren et al., Ecol. Monogr., in press.

19. We thank T. J. Minnick for bringing the data sets to our attention and H. W. Polley for comments that improved the manuscript. Support included a NASA Graduate Student Fellowship in Global Change Research to R.D.A., the Shortgrass Steppe Long Term Ecological Research Project (NSF grants DEB9632852 and BSR-8114822), a National Park Service Agreement (12682-9004, CEGR-R92-0043,174), and NSF grant DEB-9708596. The Central Plains Experimental Range is administered by the U.S. Department of Agriculture's Agricultural Research Service. 